\title{
On Some Properties of Science Fiction Dystopian Narrative
}

\author{
Gaiane Muradian, Anna Karapetyan \\ Yerevan State University
}

\begin{abstract}
Dystopia is a narrative form of fiction in general and of science fiction in particular. Using elements of science fiction discourse like time travel, space flight, advanced technologies, virtual reality, genetic engineering, etc. dystopian narrative depicts future fictive societies presenting in peculiar prose style a future in which humanity has fallen into destruction, ruin and decline, in which human life and nature are wildly abused, exploited and destroyed, in which a totalitarian, highly centralized, and, therefore, oppressive social organization sacrifices individual expression, freedom of choice and idiosyncrasy of the society and its members. It is such critical and creative reflections of science fiction dystopian narrative that are focused on in the present case study with the aim of bringing out certain properties in terms of narrative types and devices, figurative discourse and cognitive notions through which science fiction dystopia expresses and conveys its overarching message, i.e. the warning to stop before it is too late to the reader.
\end{abstract}

Key words: science fiction, dystopian narrative, narrative types and devices, figurative discourse, cognitive notions.

Our Golden Age is long buried in our ashes.

(Sicoe 2013)

\section{Introduction}

Dystopia (from the Greek $\delta v \sigma$-for bad, not good and tómos for place), the antonym of utopia (a blueprint for an ideal society with minimal crime, violence and poverty) was coined by English philosopher and economist J.S. Mill in 1868 
(Mill 1988). As a genre or narrative form of fiction, it appeared in the $20^{\text {th }}$ century and became very prevalent in the years after World War II. Science fiction dystopian narrative depicts imaginary worlds, states and societies, typically totalitarian and degraded ones, in which people lead dehumanized and often fearful lives (Merriam-Webster 2017; English Oxford Living Dictionaries 2017). Such societies are characterized by authoritarian governments, environmental disasters, cataclysmic decline in human relations. However artistic and imaginative the science fictional dystopia set in the future, it reflects the present fears and anxieties and draws attention to real-world problems regarding society, politics, economics, religion, psychology, ethics, science, technology and warns us to stop destructing our world if we want to survive.

The language of such a form of narrative is unique, vivid, full of expressive means and stylistically charged linguistic elements, in addition to cognitive tools which contribute to carrying the message of the genre to the reader. Thus, the aim of the present paper will be to explore this unique literary form considering normative narrative writing, and to make apparent certain properties of science fiction dystopian narrative from a linguistic perspective.

\section{Narrative Types and Devices in Science Fiction Dystopia}

Remaining largely unconcerned with good or bad literature, narrative is always with us - international, trans-historical, transcultural like life itself (Barthes 1975:237). Dystopia is the narrative type that reflects pessimistic world-view. In a specific narrative form science fiction (sf) dystopia often describes how humanity destroys nature and natural bonds, and can range from partial or total estrangement from them, to the catastrophic destruction of natural environment up to where life can no longer be sustained. This is ecological dystopia (1). The dystopia narrator often reflects the fact that one or more large corporations, completely ruling the world, can dominate the human mind through manipulation, propaganda, intrusive advertisement and even through implanted technology, or they can dominate the human life through absolute control of resources and a strict limitation of available comforts. This is economic dystopia (2). Sf authors often consider government 
to be the root of all the evil. This can be the government of a single nation, or a global government system, in which case dystopia crushes an otherwise utopian premise of unity. Society is controlled and limited by the very institutions that are supposed to protect it, ranging from presidents to law enforcement structures. Personal freedom is a myth, trust is a commodity no one can afford, and the system disregards human rights down to treating people like livestock. This is political/totalitarian dystopia (3). Generally, in sf dystopian narrative, the future society is controlled by a dangerous ideology or religion which slowly destroys human relations and everything spiritually valuable that humanity has built along the road. This is spiritual dystopia (4). Spiritual dystopia may result in another, a most dangerous form of itself which is the kind the one sets up in one's own mind. This is internal dystopia (5) motivated by fear, misinformation, manipulation and isolation crippling a society from within even more effectively than through political means. And finally, contrary to an economic and political dystopia where a bunch of people control all others by means of technology, technological dystopia (6) narrates the consequences of technology itself ravaging the lives of people. The narrator focuses on man-slaughtering robots, androids, simulacra, clones to man-enslaving ones. Also, the author attaches great importance to humankind becoming entirely dependent upon technology to accomplish even the simplest tasks. A variant of this dystopia is "the science-turned-rogue kind", where usually a virus or genetic modification destroys humanity (Sicoe 2013).

Often, in dystopian sf, the reader experiences the dystopia through the protagonist's point of view because the narration is presented through the perspective of a single protagonist who questions the social and political order. As a result, social and political language, notions and concepts abound. The positive characters are complex too because they are combating grand ideas and going against a powerful totalitarian order. The combat/conflict is a key to the dystopian narrative: the protagonist, either single or in a group, rebels against the dystopian reality and this conflict makes the plot, which is complex, attractive and interesting. However, in much the same way, the 
dystopian plot deals with the imperfect - the acts of the protagonist often fail giving rise to hopelessness. Very often the plot necessitates and furthers the conflict between the protagonist and the system or its representatives to its highest level. In this case, forceful actions against the system are encouraged, but they can result in violence depicted in very descriptive narrative forms. Therefore, the protagonist, the positive characters, the combat/conflict, the plot, the system and violence are narrative devices typical of nearly all science fiction dystopias.

Dystopias usually have an alienated character that refuses the dominant society, and it is precisely this narrative element that establishes the text's capacity for social critique and the "utopian anticipation in the dystopian text" (Moylan 2000:147).

\section{Figurative Language and Cognitive Notions in SF Dystopian Narrative}

Since the mid-20th century sf utopian fiction has especially become irrelevant and dystopian fiction has gained power. Sf dystopia extrapolates terrifying nearfutures from disturbing current trends of today. "In order to quickly create an atmosphere that is at once plausible and terrifying, dystopian writers almost universally turn to an idea certain to generate both fear and sympathy in the reader - the dual concept of language as the primary tool by which repressive societies stifle dissent, and simultaneously as the primary weapon used by rebels bent on understanding, resisting, and countering such oppression" (Sisk 1997:7).

The emphasis on language has always remained a key element in sf dystopian narrative. Sf dystopia imposes authoritarian control over language in order to prevent the formulation of heterodox thought (Meyers 1990:198); the representation of discourse in the narrative is necessarily related to the nature of the society in which the linguistic acts take place (Marcus 1999:2). However, this does not mean that if the sf dystopian society is exposed to numerous limitations and manipulations (including linguistic ones), there is no place for artistic, beautiful and expressive language to describe in narrative form the "dark" society. In addition to expressive language, the analysis of dystopian narrative demonstrates that there are things the reader needs to know and 
experience outside of language (cognitive notions) because language mediates reality, but there is also the very fictitiousness/figurativeness of language that impacts the reader securing the comprehension of the factitious part of the message.

Sf dystopian narrative is fundamentally characterized by the reflection of the cognitive notions referring to problems of socio-political and cultural context that produces them. For example, George Orwell's Nineteen Eighty-Four, a totalitarian (also spiritual and internal) dystopia written in 1949, focuses on powerlessness of the individuals in the face of the oppressive and brutal government run by a totalitarian dictatorship, paranoia among the citizens who live in fear (they are constantly monitored, betrayed or abused). Here language is used as a political medium to conceal the truth from the public, to manipulate and brainwash people, to make them accept all propaganda as unmistakable. These cognitive notions are supported by a highly imaginary Orwellian narrative language aimed at evoking emotional experiences in the readers. Orwell's fictional character and dystopian protagonist Winston Smith is depicted as feeling a previously-repressed desire grow from within; he is determined that everything is terribly wrong with the society in which he lives. What sets him and his girl-friend apart from the countless others is their willingness to challenge presumptions and their courage to risk comfort to know and make life better. They both feel trapped and are struggling to escape from the existing repressive system. The essence of the system is presented in the following utterance:

BIG BROTHER IS WATCHING YOU.

(Orwell 1990:2)

The cognitive notion underlying the above sentence is related to the totalitarian, anti-democratic system of government control. On the linguistic surface, the notion is introduced by an expressive figurative usage - a genuine metaphor created by the author. In this case the functional aim (both cognitive and expressive) is carried out by a sentence but in general it may be presented by units larger than a sentence, groups of sentences of varying lengths, even up 
to the work as a whole, and by units smaller than a sentence - by the syntagma and the word. Seemingly one sentence, actually the above narrative may be broken down into other functional units: (1) big brother, (2) is watching, (3) you. The first unit is coined by George Orwell himself, it expresses the idea of a certain power (negative) over people. At first sight protective as a brother, in reality this power takes advantage of its position to control others. The second unit expresses the position of the big brother who is always watchful and ready to notice and punish any misconduct. The rules of conduct have been set by this power beforehand. The third unit functions as an indicator of the target, i.e. the lower-class Proles (from proletariat)_under the control of the big brother. The Proles make up the majority of the population and represent the uneducated working class (the you in the example). The figurative utterance with the underlying cognitive notion has an initial importance for the work taken as a whole, as this sentence may be considered the gist of the whole narrative. In the context big brother is the dark-eyed, mustachioed embodiment of the single party that rules the dystopian superpower of Oceania.

George Orwell uses an indirect discourse throughout his narrative structure, which basically means that he uses a certain style of third-person narration, using some third-person characteristics. Along with the essence of first-person direct speech, this enables a unique impact on the reader. Through both first and third person narrative, the reader experiences the events and the feelings of the characters as they are happening. George Orwell also uses the common narrative structure of a beginning, a middle and an end, being told in chronological order, which makes the plot much easier to follow, and the story to flow better.

Let us try to identify figurative discourse and cognitive notions of power and control in Huxley's Brave New World (first published in 1932). The following examples of spiritual/internal dystopia show that Huxley's narrative style and figurative language are centered on the depiction of human loneliness and isolation while conceptualization is based on misuse of technology, especially those allowing the manipulation of human brain and genes aimed at destructing spiritual experiences and creating a dehumanized society. The assumption that 
there will always exist those who use technologies for personal gain, and as an attempt to maintain power and control, is another cognitive notion.

"But all the same," insisted the Savage, "it is natural to believe in God when you're alone - quite alone, in the night, thinking about death."

The words awoke a plaintive echo in Bernard's mind. Alone, alone... "So am I," he said, on a gush of confidingness. "Terribly alone."

"Yes, that's just it." The young man nodded. "If one's different, one's bound to be lonely."

"Alone, always alone," the young man was saying.

He was as miserably isolated now as he had been when the service began - more isolated by reason of his unreplenished emptiness, his dead satiety.

Alone even in Morgana's embrace - much more alone, indeed, more hopelessly himself than he had ever been in his life before.

And then he spends most of his time by himself-alone.

He was like a man pursued, but pursued by enemies he does not wish to see, lest they should seem more hostile even than he had supposed, and he himself be made to feel guiltier and even more helplessly alone.

Most of Bernard's isolation is self-imposed.

Mental excess could produce, for its own purposes, the voluntary blindness and deafness of deliberate solitude, the artificial impotence of asceticism.

(Huxley 2006:47)

The theme of loneliness is the gist of Huxley's figurative discourse and is observed in many chapters of the story. The repetition of the words alone and lonely and their semantic analogies (isolation, isolated, solitude, by himself) strengthen the stylistic effect of the utterances and respectively - the emotional 
impact on the reader. The impact becomes still more powerful through the successive repetition of the word (alone, alone) and the usage of such intensifiers as quite, terribly, always, more, miserably, hopelessly, even more helplessly. It is evident that the controlled mass entertainment and the seemingly happy life make people spiritually crippled, and this is what the system is striving to do in all totalitarian regimes.

It is clear from the example below that books are burnt in Ray Bradbury's Fahrenheit 451 (1953) because, put in figuratively, $A$ book is a loaded gun in the house next door, a very dangerous weapon because it can open the human hypnotized minds.

We must all be alike. Not everyone born free and equal, as the Constitution says, but everyone made equal. Each man the image of every other; then all are happy. So! $A$ book is a loaded gun in the house next door. Burn it. Take the shot from the weapon, breach one man's mind.

(Bradbury 1953:58)

The above quote around which the whole narrative revolves, is the core of the plot in Fahrenheit 451. Books provide outside knowledge, and due to this new knowledge people will realize that they are forced to live in a seemingly perfect society and will rebel against the system.

The same idea is observed in Huxley's Brave New World (2006) where the system pre-conditions its inhabitants into artificial roles and anti-riot speeches, rendering them able to see only the single world-view imposed on them. This is done through eradicating the past: by a campaign against the Past, by the closing of museums, the blowing up of historical monuments, by the suppression of all books.

Accompanied by a campaign against the Past; by the closing of museums, the blowing up of historical monuments (luckily most of them had already been 
destroyed during the Nine Years' War); by the suppression of all books published before A.F. 150.

(Huxley 2006:36)

In general, there are many situations of internal dystopia, each corresponding to elements of figurative discourse narrating the ruling powers. The largest motivating component is fear, typically from isolation, change and punishment. These are the main motivators in self-imposed dystopian behaviors that hold people back from experiencing life in fuller ways. To fully experience the joys and wonder of humanity, humans must live in a normal society, take responsibility for their actions, keep their eyes and minds open to greater understanding and deeper knowledge, value the life around them, and embrace themselves as members of existence.

Sf dystopian narrative is also characterized by the reflection of the cognitive notion of the more advanced technology available only to the group in power to improve their oppression, and thus the narrative features technology more advanced than we have today, and the group in power controls it. As in any kind of narrative, in sf narrative too, it is the character that shapes the story, makes the reader follow and get involved in it. The character can also be a robot, an android, a machine, other genuine invention of technology, which is presented in a detailed description. The dehumanizing nature of the society and a negative achievement of technology depicted in Fahrenheit 451 is best reflected in the mechanized Hound that is used to sniff out nonconformists:

"It doesn't like me," said Montag.

"What, the Hound?' The Captain studied his cards. "Come off it. It doesn't like or dislike. It just functions. It's like a lesson in ballistics. It has a trajectory we decide for it. It follows through. It targets itself, homes itself, and cuts off. It's only copper wire, storage batteries, and electricity."

(Bradbury 1953:12) 
As an inanimate object, the Hound is depicted in such figurative usages as the metaphor It doesn't like or dislike, in the literal/literalized metaphor It's only copper wire, storage batteries, and electricity and in the simile It's like a lesson in ballistics.

Dystopian narrative is mostly the product of the $20^{\text {th }}$ and $21^{\text {st }}$ centuries. Whether isolationist or open, insular or global, it is the cultural product of the age of discovery, technology and social structure. War, famine, disease, state terror, dictatorship, genocide, ecocide have provided fertile ground for this fictive/figurative underside of human imagination. This narrative type has produced challenging cognitive maps of the given historical situation by way of imaginary societies which are even worse than those that lie outside the author's and the reader's world.

\section{Conclusion}

Narrative is the primary means of comprehension and expression for our experience of events changing over time. The descriptive sf dystopian narrative that uses figurative language techniques with underlying socio-technological cognitive notions is presented in stories about oppression, dictatorship, devastation of the world by pollution, overpopulation and technology, destruction of human life and mind, and finally, rebellion and survival. It borrows features from reality, is involved with the concerns of the time and discusses them, but it does not depict contemporary society in general. The most important perspective element of sf dystopian narrative presented with the help of a most expressive language is its suggestion of some kind of warning (often implicit) of what will happen should present trends continue.

\section{References:}

1. Barthes, R. and Duisit, L. (1975) An Introduction to the Structural Analysis of Narrative. // New Literary History. Vol. 6, N 2. Baltimore, Maryland: The Johns Hopkins University Press, pp. 237-272. 
2. (2017) English Oxford Living Dictionaries. Oxford: OUP. Available at: $<$ https://en.oxforddictionaries.com/definition/dystopia> [Accessed May 2017].

3. Marcus, E. (1999) Speaking the Ineffable: Language and Dystopia. // Postmodern Perspectives. London: University of North London.

4. (2017) Merriam-Webster Inc. Available at: <https://www.merriam-webster.com/ dictionary/dystopia $>$ [Accessed May 2017].

5. Meyers, W. (1990) Aliens and Linguists: Language Study and Science Fiction. Athens: The University of Georgia Press.

6. Mill, J.S. (1988) Public and Parliamentary Speeches - November 1850November 1868. Toronto: University of Toronto Press.

7. Moylan, T. (2000) Scraps of the Untainted Sky. Science Fiction, Utopia, Dystopia. Boulder: Westview.

8. Sicoe, V. (2013) Utopia and Dystopia - the Many Faces of the Future. Available at: <http://www.veronicasicoe.com/blog/2013/04/utopia-anddystopia-the-many-faces-of-the-future/> [Accessed June 2017].

9. Sisk, D.W. (1997) Transformations of Language in Modern Dystopias (Contributions to the Study of Science Fiction \& Fantasy). Westport: Praeger.

\section{Sources of Data:}

1. Bradbury, R.D. (1953) Fahrenheit 451. NY: Random House. See also R. Bradbury (Copyright 2016) Fahrenheit 451. Available at: $<$ https://canvas.instructure.com/courses/953654/files/35819853> [Accessed February 2016].

2. Huxley, A. (2006) Brave New World. New York: Harper Perennial.

3. Orwell, G. (1990) Nineteen Eighty-Four. London: Penguin Books. See also Orwell, George (Copyright 1999-2016) Nineteen Eighty-Four - 1984. Available at: <http://orwell.ru/library/novels/1984/english/> [Accessed June 2016]. 


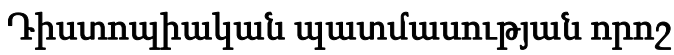 unuiddawhwunlnıpjnı\&itiph 2 nıp2}

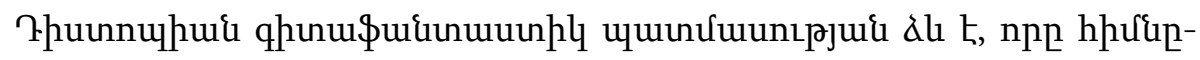

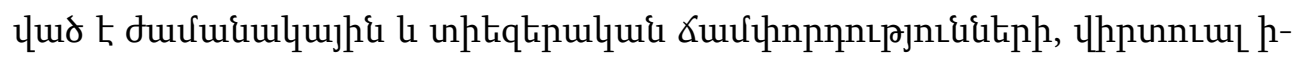

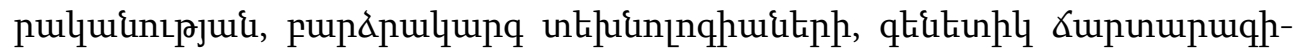

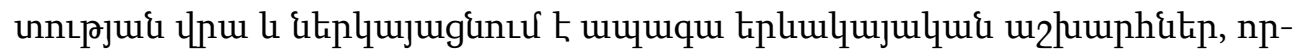

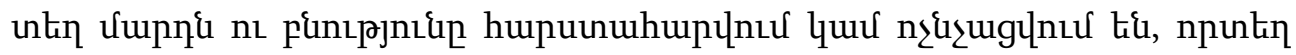

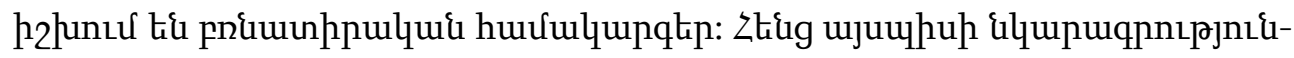

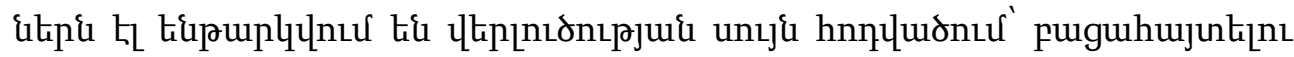

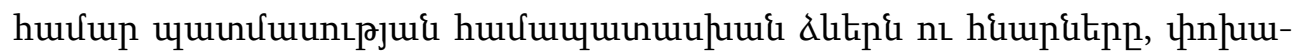

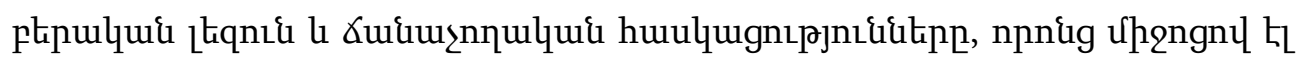

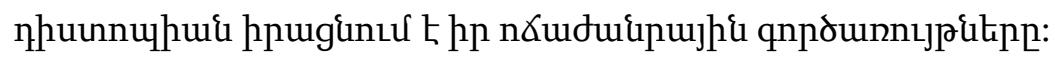

